\title{
Social versus liberal collective skill formation systems? A comparative-historical analysis of the role of trade unions in German and Swiss VET
}

European Journal of Industrial Relations 2020, Vol. 26(3) 263-278

(C) The Author(s) 2019

Article reuse guidelines: sagepub.com/journals-permissions DOI: 10.1 I77/0959680I I9844426 journals.sagepub.com/home/ejd

@SAGE

\section{Patrick Emmenegger}

Universität St. Gallen, Switzerland

\section{Lukas Graf}

Hertie School of Governance, Germany

\section{Alexandra Strebel}

Eidgenössisches Hochschulinstitut für Berufsbildung, Switzerland

\begin{abstract}
We distinguish between social and liberal collective skill formation systems and demonstrate that the German VET system is a social system with a strong (parity) role for trade unions in its governance. In contrast, unions play a considerably weaker role in the more liberal Swiss system, which privileges employers' interests. We show that the different position of unions in VET systems has the expected consequences on a range of indicators. We further examine why unions are less important in Switzerland and show how, after the First World War, differences in the institutional environment and power resources of the union movements set Germany and Switzerland on different paths, which are still visible today.
\end{abstract}

\section{Keywords}

Employers, Germany, skill formation systems, Switzerland, trade unions, VET

\footnotetext{
Corresponding author:

Patrick Emmenegger, School of Economics and Political Science, Universität St. Gallen, Müller-FriedbergStrasse 8, 9000 St. Gallen, Switzerland.

Email: patrick.emmenegger@unisg.ch
} 


\section{Introduction}

Collective skill formation systems have attracted considerable attention in the literature on coordinated capitalism (Thelen, 2014). Four features distinguish them from other vocational education and training (VET) systems (Busemeyer and Trampusch, 2012: 14-15). First, they are dual systems, with training in both schools and firms. Second, firms are strongly involved in their provision and administration. Third, they provide occupational skills that are portable, certified and standardized beyond the firm level. Fourth, intermediary associations such as employers' associations and trade unions participate in the administration, governance and reform of training.

In the international literature on collective skill formation systems, there is a strong focus on the German system (Hall and Soskice, 2001; Streeck, 1992; Thelen, 2004). Given the size of the German economy and its central role in world markets, this focus is understandable. However, there are also other countries with such systems. Switzerland is in many ways a prototypical collective skill formation system, with proportionally the world's largest apprenticeship system (Busemeyer and Trampusch, 2012; Trampusch, 2010). The predominant focus on Germany in the literature may overgeneralize features that are specific to the German system.

In this article, we examine a striking difference between the otherwise very similar German and Swiss VET systems. To compare these two cases, we draw on the comprehensive database of the Organisationen der Arbeitswelt (OdA, Organizations of the World of Work) which are responsible for initial VET in Switzerland, and we demonstrate that unions play a considerably weaker role in the Swiss system. We do not argue that unions play no role in the Swiss system. Like all such systems, the Swiss system features a high level of social partnership and corporatist decision-making and emphasizes consensus rather than conflict.

However, there are varieties of collective skill formation systems, analogous to the famous distinction by Katzenstein (1985) between 'liberal' and 'social' forms of corporatism in small states. Most notably, Germany is an example of 'social' collective skill formation with a strong (parity) role for unions in VET governance. In contrast, Switzerland features a more liberal system with structurally privileged employers. This distinction between social and liberal systems is not yet another case of what Baldwin (2009) refers to as the 'narcissism of minor differences'. Unions are key actors in educational systems in general (Iversen and Stephens, 2008; Moe and Wiborg, 2016) and collective skill formation systems in particular (Busemeyer and Trampusch, 2012; Thelen, 2014). Therefore, we should also expect the German and Swiss systems to differ systematically with regard to the outcomes of their training systems.

We make three contributions. In the next section, we document the different roles of unions in the German and the Swiss VET systems. Subsequently, we show that the different position of unions has the expected consequences on a range of indicators (although we are not in the position to claim a causal relationship). Finally, we examine the reasons for this puzzling difference in union involvement in VET governance. We show how during the critical period after the First World War, differences in the institutional environment and the power resources of the union movements set Germany and Switzerland on different paths. Given the path-dependent nature of most political processes (Mahoney, 
2000; Thelen, 2004), these differences are still visible today. We conclude by offering some reflections on how the role of unions may influence the viability of these systems in the future.

\section{Unions in collective skill formation}

In this section, we compare the role of unions in VET in Germany and Switzerland. The German system relies on a multilevel system of governance bodies, and unions are systematically represented at all levels, although actual practice occasionally differs from the formal rules. In the Swiss system, union involvement is far less systematically regulated, not least because Switzerland does not feature a comparable system of chambers and work councils. Instead, private intermediary organizations are primarily involved through OdA. These organizations are typically employer dominated, which leaves unions with only a limited role in VET governance. Finally, we show that collective agreements play a more significant role in VET in Germany than they do in Switzerland.

\section{'Social' collective skill formation in Germany}

We examine the important role of unions in the German VET system, by first establishing where union representatives are located within its multilevel structure. We then describe this structure and, in particular, the tasks of work councils at company level and the VET boards at regional, Land and national levels, all of which prominently include union representatives. Furthermore, we sketch the essence of the process that leads to updating VET regulations to illustrate the extent of union influence. We also outline the sectoral logics of unions and collective bargaining in Germany, which helps to understand why (compared to Switzerland) there is some (limited) potential for open class conflict in the German VET context.

Embedded within a coordinated market economy (Hall and Soskice, 2001), Germany's social partners are extensively involved in the dual-corporatist structures of the VET system (Busemeyer, 2009; Greinert, 2004), which is characterized by well-defined cooperation between the stakeholders to ensure that key decisions are based on consensus (Graf, 2018; Hippach-Schneider and Huismann, 2016). These stakeholders comprise the federal and Land governments and the social partners, consisting of employers, mostly represented by employers' associations, and employees, who are generally organized through the major trade union in each sector (Saniter and Deitmer, 2013).

German unions have been suffering from decreasing membership, but their influence in VET matters has evolved historically and remains deeply institutionalized. At firm level, union power is secured through the presence of work councils (Betriebsräte). Although today less than 20 percent of the German workforce are union members, 77 percent of work councillors are still members of affiliates of the Deutscher Gewerkschaftsbund (DGB) (Dribbusch and Birke, 2012). The impact of unions in large firms is further expanded through labour relations directors (Arbeitsdirektoren), who are mostly selected by unions (Wolf, 2017: 616).

Unions also benefit from their legally prescribed right to appoint employee representatives to the VET boards at the regional, Land and federal levels. The 
Berufsbildungsgesetz (BBiG) defines unions as the entities to propose employee representatives for these boards, though it does mention the possibility of other types of employee organizations to assume that responsibility.

These boards play a decisive role in maintaining the consensus principle so crucial for the German VET system (Hippach-Schneider and Huismann, 2016). Therefore, a more comprehensive understanding of their structural and organizational characteristics is necessary. At the regional level, the numerous sectoral Kammern (chambers) are declared 'competent bodies' to establish legally regulated VET boards. These boards comprise 18 members equally distributed among employee and employer representatives as well as teachers from vocational schools. At Land level, the VET boards are built in a similar fashion, also uniformly offering two-thirds of the 18 available seats to the social partners, although one-third is reserved to members of regional governments. At the federal level and as a constitutive part of the Bundesinstitut für Berufsbildung (BIBB, Federal Institute of Vocational Education and Training), the main board maintains the equal distribution of influence among the social partners and the Länder ( 8 seats each) but, in addition, includes five federal state representatives granted a total of eight votes to be cast unanimously.

Being quasi-governmental establishments, the VET boards at Land and federal levels must facilitate impartiality and a fair distribution between employers and employees. Even Kammern as self-governing bodies, which otherwise organize and represent employer interests, must include unions in VET governance. Hence, at all levels, unions are prominently involved. However, unions cannot take their formal rights for granted. For instance, the DGB is concerned that because of rising cost pressures, firms are less willing to give employees time off to participate in VET governance tasks such as auditing examinations (DGB, 2019).

Having established where employee representatives and, more specifically, union members are located within the German VET governance system, we sketch some of these boards' most relevant tasks. Our description begins at the firm level, characterized by the presence of work councils, which are concerned with observing and evaluating work-based training and with resolving potential problems with the employer. The latter is obliged to listen to any matters regarding VET that the council wishes to discuss (Dicke and Glismann, 1996: 14). In their central role in initiating change, unions are particularly involved in processes of adapting training regulations and framework curricula to meet evolving labour market developments (Hippach-Schneider and Huismann, 2016: 15). In this regard, unions require on-the-ground information on day-to-day occurrences within firms, which can ideally be secured through the presence of work councils.

VET boards within Kammern are authorized to set up rules of the game, the most important of which are those concerning the monitoring of training companies and the actual training within firms as well as organizing the examinations. For these regulations to be implemented, they have to be approved by the general assembly (Vollversammlung) of each chamber (Dicke and Glismann, 1996: 8). However, when organizing examinations, chambers and their VET boards cannot autonomously define qualification requirements but should respect national framework curricula and training regulations. These are defined through complex processes of coordination that involve all relevant 
stakeholders. 'As a rule, the initiative to update the content or structure of a training occupation or to develop an entirely new occupation comes from industry associations, from the top-level employer organizations, from trade unions or the BIBB' (HippachSchneider and Huismann, 2016: 38). These initiatives are then evaluated and, if approved by all social partners, implemented. In this process, social partners' umbrella associations give expert opinions and collaborate with the BIBB and the ministries which are responsible for drafting compatible school curricula. Thus, the chambers' self-governance is constrained by state sovereignty regarding educational matters, which applies first and foremost to the school-based part of the dual apprenticeship training (Dicke and Glismann, 1996).

Unlike the chamber-level VET boards, the state boards are not allowed to issue binding regulations. They assume a consultative role by advising the Land governments through articulating coordinated VET positions. At the federal level, the main board also takes on a consultative task, as it 'advises the government on fundamental issues of incompany vocational training and is involved in setting standards and designing training regulations' for occupations within the dual system (Hippach-Schneider and Huismann, 2016: 15). Moreover, it is responsible for deciding on various matters regarding the governance of the BIBB, which includes for instance defining its research programme.

Apart from their simultaneous presence in these boards, unions and employers' associations face one another in collective bargaining, which also covers apprentices. German sectoral collective negotiations encompass apprentice pay and, less commonly, can result in legally binding rules on the number of training places that firms must offer (Wolf, 2017: 622). The fact that both unions and employers' associations are organized by sector facilitates the arrangement of such negotiations but inevitably renders the German system, in comparison with the Swiss one, more prone to class conflict. However, the consensus principle and strong collaboration within the VET boards has, thus far, usually been effective in keeping such disagreements at bay.

\section{'Liberal' collective skill formation in Switzerland}

We next review the role of unions in the governance of Swiss VET. First, we discuss the important role of the OdA and show that these organizations are typically employer dominated. We build on the first comprehensive database of these organizations created in 2017 and 2018 (Emmenegger et al., 2018). Second, we show that collective agreements play a small role in Swiss VET. Third, we turn to the role of non-public actors in federal commissions. It is here that unions play an important role, but it is mostly as veto players in a system otherwise dominated by employers.

The Swiss VET system is strongly governed by federal regulations, which are typically used for the strategic development of the system (Barabasch et al., 2009; Gonon and Maurer, 2012). Cantons play an important role in implementing VET at the regional level, providing school-based training, organizing examinations, vocational counselling and monitoring firms' training activities. Finally, private actors are involved in VET governance through OdA, which is an umbrella term to denote all the non-public intermediary organizations involved. 
The OdA play two key roles in the Swiss VET system. First, many of them are recognized by the federal state as responsible for at least one of the approximately 230 initial VET occupations in Switzerland. As a result, they are typically organized along occupational (not sectoral) lines. In this function, they define the content of national training regulations and framework curricula (Barabasch et al., 2009; Gonon and Maurer, 2012). Second, they are involved in the strategic development of the VET system at the federal level.

We first turn to the role of OdA as organizations responsible for an occupation in initial VET. By delegating content definition to them, public authorities aim to ensure that VET provides the skills the labour market needs in order to facilitate education-towork transitions. Importantly, they must organize and represent the interests of host companies, but they may also represent employee interests (SBFI, 2018).

There are currently 146 OdA publicly recognized as responsible for one or multiple occupations in initial VET. In our survey, based on a review of all their statutes and websites, we looked at what interest groups these organizations represent. Following Höpflinger (1984), we distinguish between company associations, occupational associations, occupation-based employee organizations and industrial unions.

On the employers' side, company associations are straightforward employers' associations, which are nationally represented by the Schweizerischer Arbeitgeberverband (SAV, Swiss Employers' Association). By contrast, occupational associations are, in an international perspective, more unusual, but they have a long tradition in the Swiss political economy. They organize self-employed professionals (crafts) and domestic marketoriented, small-business owners (Höpflinger, 1984: 168). At national level, the approximately 250 occupational associations are represented by the Schweizerischer Gewerbeverband (SGV, Swiss Trade Association). Switzerland is thus unusual in having two large peak-level employer associations, which organize different sections of the economy and are about equally strong (Kriesi and Trechsel, 2008).

On the employee side, there is no comparable parallel structure between occupationbased employee associations and industrial unions. Nevertheless, there are two peaklevel confederations active in VET governance: the Schweizerischer Gewerkschaftsbund (SGB) and Travail Suisse. However, this division primarily reflects the ideological origins of the trade union movement rather than economic interests.

Among the OdA publicly recognized as responsible for an occupation in initial VET, almost all (97 percent) represent employer interests. Only 15 (10 percent) represent employee interests, including ten which represent both sides; but none of these is affiliated to a trade union confederation. Put differently, at the level of occupations, the 'strong position of the [occupational] associations ... and the employers [comes] at the expense of the position of trade unions, whose influence is relatively weak in comparison to the unions in Germany' (Rohrer and Trampusch, 2011: 148). In other words, in the case of initial VET, union involvement is the exception rather than the rule-even though unions, where they exist, are typically involved in the drafting of training regulations.

The unions' limited role in the administration, governance and reform of training at the occupational level is also reflected in the limited role of collective agreements in the Swiss VET system. They play such a small role that the most comprehensive textbook presenting the system (Wettstein et al., 2014) does not even mention them. Part of the 
reason may be found in the fact that in Switzerland, the main private actors in VET governance are often organized along occupational lines instead of sectoral lines as in Germany (Emmenegger et al., 2019). In addition, while occupational associations of employers have a long tradition and are strongly involved in VET governance, occupation-based employee associations have virtually disappeared over time. As a result, employers' occupational associations often lack an employee counterpart.

Hence, in a comprehensive survey of the role of collective agreements in VET, Trampusch et al. (2010: 2) observe that although Swiss collective agreements 'partially determine the apprentices' wages as well as their working conditions (in particular: vacations)', this regulation 'is far less comprehensive and standardized' compared to Germany. In addition, they note that while there may be examples of sectoral training funds based on collective agreements, they are certainly dwarfed by those administered by OdA: Our survey shows that 35 of these manage such funds. However, given the predominance of employer interests in these organizations, the administration of these funds does not involve trade unions, and only four of these 35 OdA also represent employee interests.

In addition, private actors (i.e. OdA) occupy a key role in the strategic development of the VET system at the federal level. Here, unions play a more important role because the federal government aims to avoid conflict and foster consensus by including the stakeholders (the two employers' associations and both trade union confederations) in policy-making (Rüegg, 1987: 11-12). Together with representatives of the cantons and the federal state, these four actors meet annually to discuss strategic challenges, reflecting the general consensus-orientation of Swiss policymaking and the importance of social partnership. Yet although employer and employee interests are formally represented on a basis of parity, a closer look at relevant federal-level commissions shows that the employee side is structurally disadvantaged (Ebner and Nikolai, 2010; Farago, 1980).

For instance, in the Eidgenössische Berufsbildungskommission (EBBK, Federal Commission on Vocational Education and Training), which provides a forum for strategic discussions with all actors involved in VET governance, 9 out of 15 seats are reserved for non-public actors; but while the peak-level organizations of employers and employees occupy one seat each, the remaining five typically go to OdA responsible for an occupation, which are typically dominated by employer interests. Other federal commissions show a similar picture. We thus agree with Gonon and Maurer (2012: 129), who observe that 'employers play an important role in the development of VET, whereas trade unions have a much weaker leverage on policy formulation and implementation'. Although their involvement in federal commissions gives unions the opportunity to influence the strategic development of VET, this role is limited. Their minority position in these commissions and their limited role at the occupational level leaves them veto players in a system mostly aimed at avoiding conflicts and fostering consensus.

In sum, unions play a rather marginal role in the Swiss VET system, which sharply contrasts with the German case. This raises two questions which we address below. First, how does strong union involvement influence a VET system, and second, why do unions play an important role in the German system but not in the Swiss one? 


\section{Does it matter?}

Broadly speaking, the political economy of skills literature (Busemeyer and Trampusch, 2012; Greinert, 2004; Thelen, 2004) argues that unions in Germany tend to have a clear preference for promoting general as opposed to firm-specific skills in apprenticeship training. In addition to emancipatory goals, this preference is linked to a desire to decrease workers' dependence on individual employers. Concurrently, the proportion of productive work in the firm as against schooling should be relatively low. Furthermore, German unions argue in favour of decent apprenticeship wages. If these demands increase training costs for firms, unions prefer employers to carry such costs or the costs be met out of public funds. Finally, unions have a strong interest in apprenticeship training as an important recruitment channel.

Given the strong role of unions in the German VET system, we should expect German apprentices to attend more school-based training, to earn higher wages and to spend less time on productive tasks than their Swiss peers. In addition, we should expect German firms to shoulder a larger share of training costs. In recent years, researchers have made great progress in gathering data on these issues. In a nutshell, the empirical evidence indeed corroborates our expectations about a 'social' German and a 'liberal' Swiss VET system.

In a comparative study, Dionisius et al. (2009) show that Swiss apprentices spend more time on productive tasks than German ones: 'the share of the time allocated to nonproductive activities to German apprentices exceed the corresponding values for Swiss apprentices by $36 \%$-points in the first year, $28 \%$-points in the second year and $18 \%$-points in the third year' (p. 12). At least part of this difference can be explained by the time apprentices spend in school-based (rather than firm-based) training: The average difference between Germany and Switzerland amounts to 15 days in the first year of training, 10 in the second and 8 in the third. Taking time spent in internal and external courses as well as internships in other establishments also into account increases the difference to 23 days in the first year, 18 in the second and 13 in the third. While it is difficult to draw a causal link between union involvement and time spent in non-productive tasks as against school-based training, Swiss unions have long advocated the expansion of school-based vocational education (Gonon and Maurer, 2012: 139; Tabin, 1989: 125126). Likewise, German unions have repeatedly emphasized the importance of schoolbased training (Busemeyer, 2009: 160-161).

Not only do Swiss apprentices spend more time on productive tasks they also earn considerably less. In the metalworking sector, apprentices in Germany are paid around 29.2 percent as much as skilled workers, but those in Switzerland earn only 14.1 percent (Ryan et al., 2013). Unions play a key role in explaining this difference because apprentice pay is set by collective agreement in Germany but not so in Switzerland (Mühlemann et al., 2010). In addition, German unions continuously push for higher apprentice pay, while Swiss unions neither seek this role in pay-setting nor advocate a general increase in apprentice pay (Ryan et al., 2013: 6). Rather, their main interest lies in increasing the lowest rates offered by particular firms. Unsurprisingly, given these differences in wages and time spent on productive tasks, net costs of training are substantial for German enterprises, while training is on average profitable for Swiss firms. For a three-year training 
programme, the difference in firms' net costs between Germany and Switzerland is on average $€ 25,000$ (Dionisius et al., 2009: 21).

\section{Why this difference?}

Unions in both Germany and Switzerland historically demanded a key role in VET governance. The interwar period was a critical juncture in determining the outcome, and the situation of unions in the two countries differed in two important ways during this period. First, German unions' ability to mobilize was considerably stronger, providing the power resources necessary to secure an important role in VET governance. In addition, the German Social Democratic Party (currently Sozialdemokratische Partei Deutschlands, SPD), the unions' traditional ally, was better represented at the political level than its Swiss counterpart, both in the aftermath of the First World War and after the Second World War. Second, Swiss political institutions (in particular direct democracy and federalism) are such that cantonal authorities ultimately claimed the central task of monitoring firm-based training, thus pre-empting unions from playing a key role in this area. Given the path-dependent nature of political processes, these differences are still relevant today. Put differently, contingent events in the interwar period set into motion different event chains in Germany and Switzerland, which have relatively deterministic causal patterns, thus resulting in lasting differences (Mahoney, 2000: 511). Our comparativehistorical analysis thus confirms recent scholarship, most notably Thelen (2004), on the role of critical junctures and path-dependent processes in the development of skill formation policies.

The origins of VET systems can be traced back to the establishment of guilds in the middle ages. However, these systems began to diverge in the 19th century, giving rise to collective, liberal, segmentalist and statist skill formation regimes (Busemeyer and Trampusch, 2012). To some extent, the collective systems remained closest to traditional guild-dominated forms of training (Bonoli, 2015: 32-33). They rely on a rather complex governance structure based on cooperation between several actors and are thus prone to cooperation breakdowns (Streeck, 1992). In particular, these systems survived only in countries where skills were not too openly contested across the class divide, which means that unions accepted a key role for firms in VET, a necessary condition for the survival of strong firm-based training. More concretely, artisanal control over apprenticeship 'meant that unions developed in a context in which strategies based on controlling craft labor markets were not a viable option - which in turn meant that skill formation in industry would not be contested across the class divide' (Culpepper and Thelen, 2008: 26-28). Yet while German and Swiss unions accepted the important role of firms in the training systems, they nevertheless demanded comprehensive legislation on VET and were concerned about apprentices' working conditions in firm-based training.

The national paths began to diverge in the aftermath of the First World War. In Germany, already in November 1918, several employers' associations and unions signed the Stinnes-Legien agreement, which paved the way for collective bargaining and the creation of works councils. An unprecedented mobilization of the labour movement made this famous agreement possible (Paster, 2013: 72-79): By October and November 1918 , workers' and soldiers' councils arose throughout the country. According to Sassoon 
(2010: 48), these developments 'approximated a revolutionary situation'. At their 1919 congress, German unions also demanded a key role in VET governance and a comprehensive regulatory framework (Greinert, 1998: 85). However, they did not question the system as such but accepted the firms' role in VET (Thelen, 2004: 66-72).

Massive labour mobilization in this period resulted in several political breakthroughs for the labour movement in areas such as dismissal protection (Emmenegger, 2014: 9599) and unemployment insurance (Paster, 2013: 95-109). In the case of VET, progress was slower. Part of the problem was disagreement whether collective bargaining terms and conditions applied to apprentices; this was finally settled in 1928, when the Labour Court decided that apprenticeship contracts were indeed a type of employment contract and thus subject to collective agreements (Thelen, 2004: 70-71). But by then, mobilization had already abated (Paster, 2013). Hence the post-war period did not bring full union participation in the oversight of firm-based training, even though, as Thelen (2004: 63) insists, much of the groundwork had been laid by then.

Once the next window for reform opened in the aftermath of the Second World War, German unions reiterated their demand for comprehensive legislation on VET and a key role for unions. The combination of economic turmoil, left-wing empowerment and programmatic radicalization created a fertile ground for far-reaching union demands, while employers were keen on regaining political stability and thus willing to compromise (Emmenegger, 2014: 54-57; Paster, 2013: 111-118). German unions took advantage of this political situation to advance demands regarding the reform of the VET system. Yet once again, 'they did not seek a complete overhaul of the training system, and instead returned to demands they had first articulated in 1919, fixing their hopes on legislation to guarantee organized labor full parity rights with the system' (Thelen, 2004: 255). In addition, VET was not one of the unions' primary objectives (Crusius, 1982: 90, 95). Instead, German unions pushed demands including more comprehensive dismissal protection, most notably the 1951 Kündigungsschutzgesetz (Emmenegger, 2014: 108-111). Nevertheless, laws in 1953 and 1956 allowed union representatives to participate fully in the employer chambers' internal deliberations on training, which finally gave unions a voice in VET governance (Streeck et al., 1987: 9, 18; Thelen, 2004: 241).

However, the unions were not satisfied with their still limited role. In cooperation with the SPD, they continued to push for a comprehensive legislation of VET for some time. In 1966, the SPD drafted legislation and after the elections the same year entered government for the first time in German post-war history, as junior partner in the 'Grand Coalition'. The resulting Berufsbildungsgesetz (BBiG, Vocational Education and Training Act) of 1969 created overarching national legislation and new oversight structures with strong union involvement for plant-based vocational training, consisting of tripartite boards, for instance, at Land and national level (Thelen, 2004: 241-242). Following the 1969 elections when the SPD became the largest party, the new government further institutionalized workers' participation rights in the corporate sphere (Emmenegger, 2014: 153-155). Hence, by the mid-1970s, German unions had institutionalized their key role in VET governance and beyond. SPD and union strength at the time was such that some criticized the reforms as not going far enough, given demands for a reduced role of chambers and, more generally, less influence of employers in VET governance (Busemeyer, 2009: 79-83). 
Switzerland adopted comprehensive VET legislation in 1930. However, Swiss experience differed from Germany in two key regards. First, although Switzerland moved faster, by this time cantonal legislation had already filled much of the policy space, thus pre-empting federal regulations in certain key areas and institutionalizing the important role of cantons in VET governance (Bonoli, 2015; Gonon and Maurer, 2012). Swiss federalism is such that jurisdiction lies with the cantons unless the right to legislate is given to the federal state by a constitutional revision. Since each constitutional revision is subject to a mandatory referendum, policy change at the federal level is often delayed (Obinger, 1998). Indeed, in 1894, 53.9 percent of the Swiss voting population refused to grant the federal state the right to legislate in the area of VET (Bonoli, 2015: 31-35).

Only in 1908 was the federal state given the right to develop national framework legislation (Bauder, 2008: 17-21, 26). However, by then 14 out of 25 cantons had enacted their own regulations (Wettstein, 1987: 45). After the First World War, when an expert commission began drafting the federal law, this number had increased to 22 . The cantons claimed the right to organize examinations and oversight of firm-based training (Wettstein, 1987: 44-47). Hence one of the key demands of German unions, an important role for unions in the monitoring of firm-based training, had already been taken off the table when discussions about the new national framework legislation began. The unions accepted the cantonal responsibilities in the oversight of firm-based training (as well as the important role of firms in the training system), and this task was to remain a public duty of the cantons. In this context, it is relevant to consider the relation between cantons and businesses. For instance, Rüegg (1987: 14) argues that cantonal interests are often aligned with those of regionally dominant economic sectors, turning cantonal VET offices into the 'mouthpiece' of employer interests. Similarly, Maurer and Pieneck (2013: 191) argue that cantonal VET offices neither have the resources nor are interested in monitoring firm-based training closely.

Although Swiss unions were active participants in discussions on the federal regulatory framework for VET (Tabin, 1989: 94-99), they had nowhere near the mobilization capacity of German unions (Emmenegger, 2014). Nor did they have the support of an electorally strong party like the SPD. The discussions were thus largely dominated by employers, in particular the SGV. For instance, Bauder (2008: 37) reports that for the 1930 VET act, the draft law developed by the SGV, which emphasized the important roles of cantons, occupational associations and historically grown regional structures, served as the main basis. In contrast, the parallel proposal made by the SGB, which emphasized further measures to protect apprentices from abuse, was mostly ignored in the deliberations.

However, this conflict of interests should not be overdrawn. Swiss unions were openly supportive of the VET system despite the important role it leaves to firm-based training (Bonoli, 2015: 34; Tabin, 1989: 95). In addition, despite occasional references to class struggle in the national debate on the 1930 law, the unions cooperated with occupational associations at the regional level, which indicates that they accepted their lead role in VET matters (Bauder, 2008: 24-25, 43). The unions also supported the 1963 and 2002 VET acts, which extended the regulatory framework to further sectors but did not substantially strengthen the unions' role in VET governance (Strahm, 2008; Wettstein, 1987: 58). Yet the unions vehemently opposed the 1978 Berufsbildungsgesetz because it aimed 
to introduce short-track programmes with reduced school-based training, while the unions demanded a general strengthening of the role of general skills (Berner, 2013: 43; Ebner and Nikolai, 2010: 636; Tabin, 1989: 128-129). However, the unions lost the subsequent referendum campaign decisively.

Summing up, although social partnership characterizes the VET system in both countries, the German system awards unions a considerably stronger role. In Switzerland, cantonal VET laws pre-empted a relevant role for unions in monitoring firm-based training, while Swiss unions' weaker mobilization capacity did not allow them to secure a key role in VET governance. Partly because of the key role of unions, the German system today displays a considerably stronger sectoral focus and is well integrated into the collective bargaining system. In contrast, the Swiss system is still primarily organized along occupational lines with only a minority of OdA also concluding collective agreements. Its occupational 'logic' is likely to have contributed further to its depoliticization compared to the German system based on work councils and regional chambers. Primarily organized along sectoral lines, Swiss unions do not match up well with OdA. We thus observe an endogenous self-reinforcing process (Pierson, 2000), in which the Swiss occupational logic complicates mobilization for unions, which in turn supports the occupational logic and thus the acceptance of employers' privileged position.

\section{Conclusion}

Germany and Switzerland possess in many ways very similar collective skill formation systems. However, they differ in at least one crucial aspect. While the German system prominently involves unions at all levels, unions play a more marginal role in the Swiss system. The consequences are as the literature on neocorporatist interest intermediation systems would expect (Streeck, 1992). In the 'liberal' Swiss system, apprentices earn less and spend more time on productive tasks. In contrast, in the 'social' German system, net training costs for firms are higher, and apprentices spend more time in vocational schools. German unions also play a central role in monitoring firms' training activities, while in Switzerland this task is left to cantonal VET offices.

These differences originate in the period when trade unions became for the first time seriously interested in participating VET governance; but in the crucial 1920s, the political situation in the two countries was very different. The German unions' ability to mobilize was considerably stronger, which allowed them to claim an important role in VET governance. In addition, Swiss political institutions are such that cantonal authorities claimed the central task of monitoring firm-based training at an early stage, thus preempting any possibility of unions playing a key role in this area. In line with the historicalinstitutionalist literature on path dependency (Mahoney, 2000), these differences remain relevant today, resulting in a Swiss system that is more occupational than the German one, probably further accentuating the employers' structurally privileged position.

This difference is not necessarily bad news for the Swiss system. Collective skill formation systems have come under pressure in recent years. Most notably, it has become increasingly difficult to mobilize firms to invest in training (Thelen, 2014). Switzerland tries to address this challenge by making its system particularly employer friendly. Swiss 
apprentices earn less and spend more time on productive tasks, so training is (on average) profitable for Swiss firms, while the net costs of training are substantial for German firms. In addition, the Swiss employers' central role in VET governance suggests that they are in a good position to shape the system according to their needs.

Nevertheless, there are checks and balances in the Swiss VET system. Instead of unions, cantonal VET offices are responsible for monitoring firms' training behaviour. Like unions, they have an interest in avoiding abuse. However, within corporatist systems, public actors are probably careful to ensure that public policies do not undermine employers' collective action. In addition, regional political institutions might be captured by regional economic interests. Yet apprentices might also vote with their feet. If dissatisfied with the training possibilities, they might increasingly opt for fully school-based VET or general academic schooling, although the extent to which apprentices have a real choice of course varies.

In Germany, recent research suggests that owing to increasing labour market deregulation firms adapt their training practices by increasing the share of productive tasks for apprentices at the workplace (Jansen et al., 2015). Thus although unions are well represented at all levels, change in training practices may move the German system in the direction of the more liberal Swiss one. In collective skill formation systems, employers can be expected to constitute the pivotal actors. If they are forced to engage in too many compromises, far beyond what Streeck (1992) calls 'beneficial constraints', they might withdraw from training altogether, thus aggravating the collective action problem that any collective skill formation system faces. Hence these reflections could suggest that collective skill formation systems survive only if employers are given the keys to the engine room. Whether this is a price worth paying to ensure the future viability of these systems is a political question.

However, what our analysis indicates is that scholars interested in collective skill formation can only benefit from looking beyond the well-known German case to understand how the collective good of apprenticeship training can be provided even without strong union involvement. Without wanting to imply that the Swiss experience can be easily replicated, this finding should nevertheless be relevant for the numerous policymakers around the world aiming to build up collective governance structures for apprenticeship training - even in times of declining union membership.

\section{Acknowledgements}

An earlier version of this article was presented at the International Standing Conference for the History of Education (ISCHE) in Berlin in 2018 and an international VET workshop in Konstanz. We thank all participants as well as Lorenzo Bonoli and the members and scientific advisors of the Swiss Leading House 'Governance of Vocational and Professional Education and Training' (GOVPET) for their generous and insightful comments. All remaining errors are our responsibility.

\section{Funding}

The author(s) disclosed receipt of the following financial support for the research, authorship and/ or publication of this article: This work was supported by the Schweizerisches Staatssekretariat für Bildung, Forschung und Innovation in the framework of the Leading House 'GOVPET: Governance of Vocational and Professional Education and Training'. 


\section{References}

Baldwin P (2009) The Narcissism of Minor Differences. Oxford: Oxford University Press.

Barabasch A, Scharnhorst U and Kurz S (2009) Schweiz. In: Rauner F (ed.) Steuerung der beruflichen Bildung im internationalen Vergleich. Gütersloh: Bertelsmann, pp. 197-288.

Bauder T (2008) Der Entwicklungsprozess des ersten eidgenössischen Berufsbildungsgesetzes. In: Bauder T and Osterwalder F (eds) 75 Jahre eidgenössisches Berufsbildungsgesetz. Bern: hep, pp. 11-50.

Berner E (2013) Verbundpartnerschaft - Schlagwort oder Erfolgsrezept? In: Maurer M and Gonon P (eds) Herausforderungen für die Berufsbildung in der Schweiz. Bern: hep, pp. 37-60.

Bonoli L (2015) Deconstructing the myth of rational planning and coherent reform. In: Heikinnen A and Lassnigg L (eds) Myth and Brands in Vocational Education. London: Cambridge Scholars, pp. 44-58.

Busemeyer M (2009) Wandel trotz Reformstau: Die Politik der beruflichen Bildung seit 1970. Frankfurt: Campus.

Busemeyer M and Trampusch C (2012) The Political Economy of Collective Skill Formation. Oxford: Oxford University Press.

Crusius R (1982) Berufsbildungs- und Jugendpolitik der Gewerkschaft. Frankfurt: Campus.

Culpepper P and Thelen K (2008) Institutions and collective actors in the provision of training. In: Mayer K and Solga H (eds) Skill Formation. Cambridge: Cambridge University Press, pp. 21-49.

DGB (2019) Endgültige Stellungnahme des Deutschen Gewerkschaftsbundes zum Referentenentwurf des Bundesministeriums für Bildung und Forschung. Berlin: DGB.

Dicke H and Glismann H (1996) Schnittstellen zwischen Staat und Wirtschaft im System der beruflichen Bildung in Deutschland. Working paper 748. Kiel: Institut für Weltwirtschaft.

Dionisius R, Muehlemann S, Pfeifer H, Walden G, Wenzelmann F and Wolter S (2009) Costs and benefits of apprenticeship training: A comparison of Germany and Switzerland. Applied Economics Quarterly 55(1): 7-37.

Dribbusch H and Birke P (2012) Die Gewerkschaften in der Bundesrepublik Deutschland. Berlin: Friedrich-Ebert-Stiftung.

Ebner C and Nikolai R (2010) Duale oder schulische Berufsausbildung? Swiss Political Science Review 16(4): 617-648.

Emmenegger P (2014) The Power to Dismiss: Trade Unions and the Regulation of Job Security in Western Europe. Oxford: Oxford University Press.

Emmenegger P, Graf L and Strebel A (2018) GOVPET Database: Organizations of the World of Work. St. Gallen: Universität St. Gallen.

Emmenegger P, Graf L and Trampusch C (2019) The governance of decentralized cooperation in collective training systems. Journal of Vocational Education and Training 71(1): 21-45.

Farago P (1980) Antagonistische Interessen und Verhandlungsdemokratie: Eine Untersuchung am Beispiel der jüngsten Revision des Berufsbildungsgesetzes. Schweizerische Zeitschrift für Soziologie 6(2): 229-243.

Gonon P and Maurer M (2012) Educational policy actors as stakeholders in the development of the collective skill system. In: Busemeyer M and Trampusch C (eds) The Political Economy of Collective Skill Formation. Oxford: Oxford University Press, pp. 126-149.

Graf L (2018) Combined modes of gradual change: The case of academic upgrading and declining collectivism in German skill formation. Socio-Economic Review 16(1): 185-205.

Greinert W (1998) Das deutsche System der Berufsbildung. Baden-Baden: Nomos.

Greinert W (2004) Die europäischen Berufsbildungssysteme: Überlegungen zum theoretischen Rahmen der Darstellung ihrer historischen Entwicklung. Berufsbildung: Europäische Zeitschrift 32(2): 18-26. 
Hall P and Soskice D (2001) Varieties of Capitalism. Oxford: Oxford University Press.

Hippach-Schneider U and Huismann A (2016) Vocational education and training in Europe: Germany. Available at: http://libserver.cedefop.europa.eu/vetelib/2016/2016_CR_DE.pdf

Höpflinger F (1984) Verbände. In: Klöti U (ed.) Handbuch politisches System der Schweiz. Bern: Haupt, pp. 163-188.

Iversen T and Stephens J (2008) Partisan politics, the welfare state, and the three worlds of human capital formation. Comparative Political Studies 41(4-5): 600-637.

Jansen A, Strupler Leiser M, Wenzelmann F and Wolter S (2015) Labour market deregulation and apprenticeship training. European Journal of Industrial Relations 21(4): 353-368.

Katzenstein P (1985) Small States in World Markets. Ithaca, NY: Cornell University Press.

Kriesi H and Trechsel A (2008) The Politics of Switzerland: Continuity and Change in a Consensus Democracy. Cambridge: Cambridge University Press.

Mahoney J (2000) Path dependence and historical sociology. Theory and Society 29(4): 507-548.

Maurer M and Pieneck S (2013) Die Reform von Berufsbildern als ständige Auseinandersetzung über Form und Inhalt. In: Maurer $\mathrm{M}$ and Gonon $\mathrm{P}$ (eds) Herausforderungen für die Berufsbildung in der Schweiz. Bern: hep, pp. 81-100.

Moe $\mathrm{T}$ and Wiborg S (2016) The Comparative Politics of Education: Teacher Unions and Education Systems around the World. Cambridge: Cambridge University Press.

Mühlemann S, Pfeifer H, Walden G, Wenzelmann F and Wolter S (2010) The financing of apprenticeship training in the light of labor market regulations. Labour Economics 17(5): 799-809.

Obinger H (1998) Federalism, direct democracy, and welfare state development in Switzerland. Journal of Public Policy 18(3): 241-263.

Paster T (2013) Business and welfare state development: Why did employers accept social reforms? World Politics 65(3): 416-451.

Pierson P (2000) Increasing returns, path dependence, and the study of politics. American Political Science Review 94(2): 251-267.

Rohrer L and Trampusch C (2011) Continuity and change in the Swiss Vocational Training System. In: Trampusch C and Mach A (eds) Switzerland in Europe. London: Routledge, pp. $144-161$.

Rüegg E (1987) Neokorporatismus in der Schweiz. Zürich: Forschungsstelle für Politische Wissenschaft.

Ryan PU, Backes-Gellner S, Teuber S and Wagner K (2013) Apprentice pay in Britain, Germany and Switzerland. European Journal of Industrial Relations 19(3): 201-220.

Saniter A and Deitmer L (2013) Germany: Towards a Model Apprenticeship Framework. Geneva: ILO.

Sassoon D (2010) One Hundred Years of Socialism. London: I.B. Tauris.

SBFI (2018) Organisationen der Arbeitswelt. Bern: SBFI.

Strahm R (2008) Die entscheidenden Neunzigerjahre. In: Bauder T and Osterwalder F (eds) 75 Jahre eidgenössisches Berufsbildungsgesetz. Bern: hep, pp. 311-350.

Streeck W (1992) Social Institutions and Economic Performance. London: SAGE.

Streeck WJ, Hilbert KH, Kevelaer F, Maier F and Weber H (1987) Die Rolle der Sozialpartner in der Berufsausbildung und beruflichen Weiterbildung. Berlin: CEDEFOP.

Tabin J-P (1989) Formation professionnelle en Suisse. Lausanne: Réalités sociales.

Thelen K (2004) How Institutions Evolve. Cambridge: Cambridge University Press.

Thelen K (2014) Varieties of Liberalization and the New Politics of Social Solidarity. Cambridge: Cambridge University Press.

Trampusch C (2010) Employers, the state and the politics of institutional change: Vocational education and training in Austria, Germany and Switzerland. European Journal of Political Research 49(4): 545-573. 
Trampusch C, Eichenberger P, de Roo M, Bartlett Rissi R, Bieri I, Schmid L and Steinlin S (2010) Initial Vocational Training in Switzerland. Bern: REBECA Database Social Benefits in Collective Agreements.

Wettstein E (1987) Die Entwicklung der Berufsbildung in der Schweiz. Aarau: Sauerländer.

Wettstein E, Schmid E and Gonon P (2014) Berufsbildung in der Schweiz. Bern: hep.

Wolf S (2017) Die Rolle der Gewerkschaften bei der Gestaltung und Weiterentwicklung von Berufsbildung. Zeitschrift für Berufs- und Wirtschaftspädagogik 113(4): 614-636.

\section{Author biographies}

Patrick Emmenegger is Professor of Comparative Political Economy at the University of St. Gallen.

Lukas Graf is Assistant Professor of Educational Governance at the Hertie School of Governance, Berlin.

Alexandra Strebel is a Doctoral Researcher at the Swiss Federal Institute of Vocational Education and Training, Zollikofen. 